\title{
Peranan Tasawwuf Dalam Sosialisasi Islam Di Indonesia
}

\section{Masyhudi}

Keywords: semination, religion, sufism, islam, history

\section{How to Cite:}

Masyhudi, nfn. (2001). Peranan Tasawwuf Dalam Sosialisasi Islam Di Indonesia. Berkala Arkeologi, 21(1), 68-78. https://doi.org/10.30883/jba.v21i1.834

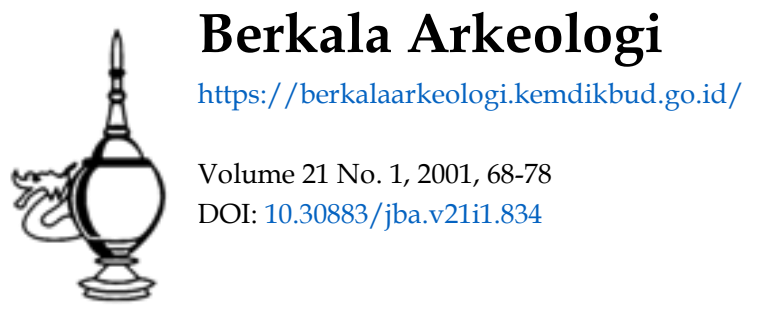

\section{(c) (i) (2)}

This work is licensed under a Creative Commons Attribution-NonCommercial-ShareAlike 4.0 International License. 


\title{
PERANAN TASAWWUF \\ DALAM SOSIALISASI ISLAM DI INDONESIA
}

\author{
Masyhudi \\ (Balai Arkeologi Yogyakarta)
}

\section{Pendahuluan}

Berbagai strategi megenai masuknya Islam di Nusantara telah banyak dibicarakan, baik oleh para peneliti asing maupun oleh para peneliti Indonesia sendiri. Strategi itu antara lain; perdagangan, politik, ekonomi dan strategi keagamaan melalui mistis/tasawwuf. Dari berbagai strategi tersebut, tasawwuf merupakan suatu kajian yang menarik dan relevan bagi perkembangan Islam dan Kebudayaan Islam di Indonesia, sebab berdasarkan beberapa kenyataan yang ada, bahwa Islam yang tersebarluas di pelosok Nusantara adalah disebabkan oleh kegiatan para sufi. Disamping itu Islam mudah tersebar di Nusantara karena daya tarik ajarannya tentang persamaan dan persaudaraan antara sesama pengikutnya dan sesama manusia, artinya Islam tidak membeda-bedakan antara seseorang dengan orang lain, antara satu suku dengan suku yang lain dan lain sebagainya.

Mengenai tasawwuf ini sering dikesampingkan oleh orientalis/peneliti-peneliti asing dari negeri Barat. Padahal sebenarnya hal ini menarik untuk dibicarakan karena dalam kenyataannya, tasawwuf telah benar-benar mampu menyingkap sumbangan besar bagi kebudayaan Islam di Indonesia, bahkan ajaran-ajarannya telah mendalam pengaruhnya dalam kehidupan masyarakat Indonesia. Bukti dari ajaran ajaran tasawuf tersebut terdapat pada beberapa hasil kesusasteraan taradisional Melayu, Aceh, Minangkabau, Bugis, Makasar, Sunda, Jawa dan lain sebagainya.

Di lapangan kesusasteraan, banyak peningggalan karya-karya sastera peningglan zaman Hindu yang masih hidup pada zaman Islam. Kesusasteraan Hindu tersebut bukan hanya sekedar dipelihara atau dilestarikam dalam bentuk fisik, tetapi disalin kembali agar tidak kehilangan arti sebagai dokumen peninggalan suatu zaman tertentu.

Di sisi lain, Masjid-masjid lama yang memiliki corak khas Indonesia dibangun berdasarkan gagasan-gagasan yang hidup di kalangan para sufi, yaitu suatu kesatuan empat yang tidak dapat dipisahkan dalam pelaksanaan ajaran Islam; syari'at, tarekat, hakekat dan ma'rifat. Di sisi lain bentuk lama dari suatu bangunan masjid dengan bentuk atapnya yang umumnya bersusun tiga ditransformasikan dalam bentuk bangunan pra -Islam. Akan tetapi dengan memberikan makna simbolis baru yang khas 
Islami, akhirnya mampu mengubah seperlunya serta menyingkirkan unsur-unsur yang bertentangan dengan Islam, sehingga lahirlah suatu konsep baru di bidang arsitektur.

\section{Sastera Budaya dan Tasawuf}

Bidang bahasa dan kesusasteraan yang berhubungan dengan kegiatan tasawuf telah memberikan sumbangan yang cukup besar bagi kebudayaan Indonesia. Hal ini terlihat pada sejumlah besar karya-karya sastera di masa lalu yang sebagian sebagian besar merupakan hasil kesusasteraan tradisional Melayu, Aceh, Minangkabau, Sunda, Jawa Madura dan lain-lain yang mayoritas penduduknya beragama Islam, dan telah memperlihatkan pertaliannya dengan dunia tasawuf.

Sebelum Islam datang di Nusantara, kesusasteraan dan bahasa Jawa mengalami pertumbuhan yang sangat pesat, namun hanya beredar di lingkungan kaum brahmana dan ksatria, yaitu kasta yang memiliki keistimewaan dalam mempelajari ilmu pengetahuan dan kesusasteraan, sehingga mereka mampu memonopoli pengembangan kebudayaan. Tetapi setelah Islam masuk dan berkembang, bukan hanya kesusasteraan dan bahasa Jawa, melainkan juga kesusasteraan dan bahasa Melayu telah mengalami perkembangan yang sangat pesat. Kemudian disusul pula dengan berkembangnya bahasa dan sastera di daerah-daerah lain seperti; Aceh, Sunda, Madura, Bugis Makassar, Minangkabau dan lain sebagainya.

Tersebarnya bahasa Melayu tersebut sebagai bahasa Lingua farnca tidak dapat terpisah dari kegiatan misi penyebaran agama Islam yang dilakukan oleh para mubaligh Islam, ulama dan sufinya, disamping faktor perdagangan. Di Ambon misalnya, pada tahun 1726 , secara kebetulan Valentjin telah menemukan naskah kitab Seribu Mas'alah, karangan Abdur-ra'uf Singkel, yaitu seorang sufi dan ulama Aceh pada abad XVII yang juga sering dikaitkan dengan pendirian Tarekat Syatariyah ( Ismail, $1983: 7$ ). Hal ini dapat dijadikan sebagai bukti bahwa, para ulama dan para sufi disamping menyiarkan agama Islam, mereka juga berperan sebagai pelaku dalam menyebarluaskan bahasa melayu. Mereka menyadari, bahwa dalam kepentingan penyebaran Islam sangat diperlukan suatu bahasa pendukung yang dapat digunakan masyarakat Indonesia yang terdiri dari berbagai suku, yaitu suatu bahasa pemersatu untuk menjalin hubunhan yang erat antara sesama anggota masyarakat. Sehingga bahasa Melayu yang tadinya merupakan bahasa lokal yang kurang berarti, akhirnya dapat tumbuh menjadi bahasa nasional, dan tentunya berkat datangnya agama Islam di Nusantara. Dalam hal lain dapat dilihat melalui berkembangnya bahasa tulis dalam bentuk sastera.

Dalam sejarah sastera Islam di negara lain, para sufi memiliki peranan yang sangat penting dalam hal perkembangan sastera, yaitu sebelum kebangkitan sastera Arab dan 
Persi dan setelah Islam lahir yang dimuali dengan kebutuhan para sufi untuk mengekspresikan pengalaman mistiknya yang mengandung kualitas puitis dan estetis. Dengan berkembangnya kesusasteraan, maka bahasa yang dijadikan sebagai media juga ikut berkembang, sehingga masuklah berbagai gagasan baru. Al-qur'an sendiri telah menantang para sasterawan muslim dengan segala keindahan yang dimilikinya, untuk melahirkan puisi-puisi yang tinggi nilainya;

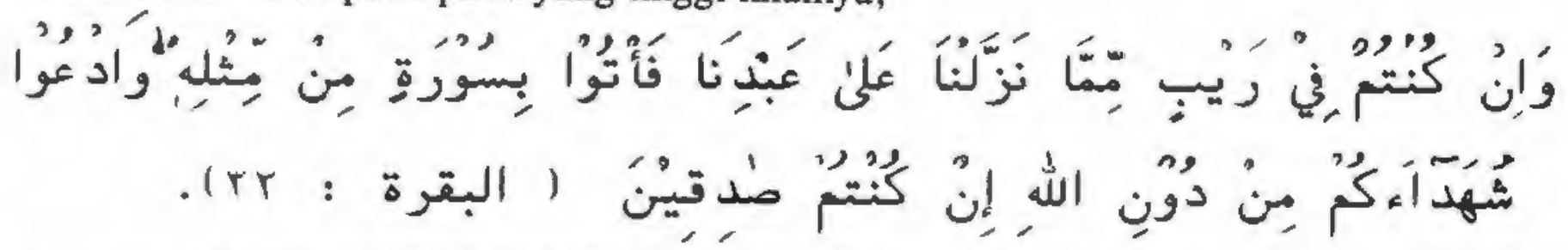

Artimya: Dan jika kamu sekalian tetap dalam keraguan tentang Al-Qur'an yang Kami wahyukan kepada hamba Kami, buatlah satu surat saja yang semisal al-Qur'an itu dan ajaklah penolong-penolongmu selain Allah, jika kamu orang-orang yang benar (AlBaqarah : 23).

\section{Tasawuf Dalam Setrategi Sosialisasi Islam di Indonesia}

Tasawwuf adalah keadaan kehidupan seseorang dalam upaya membersihkan jiwa dari pengaruh benda atau alam (keduniaan), supaya seseorang tersebut mudah menuju kepada Tuhan (Hamka, 1952: 77). Seseorang yang telah terjun kepada dunia tasawwuf maka akan menyebabkan seseorang menjadi ikhlas dalam beramal atau berjuang, yaitu hanya semata-mata karena Allah SWT, jadi bukan karena maksud yang lain. Selain itu perlu diketahui, bahwa asal dan azas agama adalah mengetahui atau mengenal Tuhan sebelum kita melakukan ibadat kepada-Nya. Hal ini merupakan hakekat perwujudan dari kalimat Syahadat (sebagai rukun yang pertama dari rukun Islam yang lima).

Dari pengertian tersebut di atas, maka kondisi semacam ini akan terdapat nilai positif dan nilai negatif. Secara positif, seseorang yang telah memasuki dunia tasawwuf akan menjadi ikhlas dalam beramal dan berjuang, yaitu hanya semata-mata karena Allah, bukan karena maksud yang lain. Akan tetapi dari segi negatifnya, seseorang akan menyingkirkan diri dari pergaulan dari masyarakat ramai dan secara mutlak memandang bahwa dunia adalah tempat beramal, bekerja, dan berjuang untuk kebahagiaan baik secara pribadi maupun masyarakat di dunia dan di akhirat. Namun yang istimewa daripada tasawwuf adalah merupakan suatu ilmu yang lebih cenderung kepada dzauq atau perasaan, jadi arahnya lebih dekat kepada seni daripada kepada filsafat.

Teori-teori tentang tasawwuf muncul dari beberpa orang tokoh terkenal, yaitu : 
1. Al-Hallaj, Al-Ghazaly, Ibnu 'Arabi, dan Ibnu Taimiyah. Teori yang digunakan oleh Al-Hallaj (Abul-Mughith Al-Husain bin Manshur Al-Hallaj bin Muhammad Al-Baidhawi) dalan dunia tasawufnya adalah :

a. Al-Hulul, yaitu bersatunya Khaliq dengan makhluk dan menjelmalah Tuhan kedalam dirinya. Akan tetapi hal ini akan dapat ditempuh oleh seseorang bila seseorang bersih batinnya dan senantiasa hidup dalam kehidupan batiniah, yang semula seseorang tersebut sebagai muslim, kemudian menjadi mukmin, kemudian sholeh, kemudian muqarrab (dekat) kepada Allah.

b. Annurul Mnuhammadiyyah, yaitu suatu keyakinan bahwa setelah cinta kepada Allah sebagai sikap yang pertama, maka harus diikuti dengan cinta kepada Muhammad, sebab Muhammad adalah penjelmaan asal bermula, yaitu allah menjelmakan dirinya menjadi Muhammad .

c. Perdamaian seluruh agama, yaitu suatu keyakinan bahwa agama adalah jalan, Islam, Yahudi, Nasrani dan agama-agama lain adalah jalan menuju Allah. Adapun orang yang mencel agama lain akan tidak bermanfaat, tak perlu berselisih tetapi dalamilah ajaran agama masing-masing, dan beramallah sesuai dengan ajaran masing-masing. Meskipun berbeda nama dan cara, tetapi maksud dan tujuan adalah sama, yaitu Allah, sebab segaala agama adalah agama Allah (Umarie, 1966 : 118).

4. Al-Ghozali ( Abu Hamid Muhammad bin Muhammad Al-Ghozali), beliau dikenal sebagai tokoh sufisme yang bergelar hujjatul-Islam, yang dapat dilihat pada karya-karyanya yang cukup banyak. Dari sejumlah karya yang ada, Ihya Ulumiddin mendapatkan kedudukan yang istimewa, karena kupasannya yang populer dan sistematis yang mencakup permasalahan-permasalahan ibadah, adab (etika), Kejahatan (kemaksiyatan), dan pujaan.

Menurut Al-Ghozali, Tauhid menyebabkan kita hanya tunduk kepada Allah. Dalam mengesakan dan mencapai pengenalan kepada Allah dan mencari ridhoNya ada beberapa cara, yaitu kita harus belajar mengenal Allah melalui tandatanda yang ada di alam semesta dan dalam diri kita sendiri, sesudah itu baru diakui bahwa Dia adalah Allah, dan itulah yang dinamakan iman. Setelah mengakui Dia adalah Allah dan membenarkan peraturan-peraturan Allah, maka muncullah ketaatan, yaitu menurut atau menjalankan segala perintah Allah yang telah tersusun secara sistematis dalam syari'at, sehingga muncullah cinta kepada Allah dan cinta kepada rasul dari lubuk hati yang dalam.

Dalam upaya mencapai tingkat makrifat, Al-Ghozali mengisyaratkan agar seseorang melepaskan dari ikatan dunia dan menetapkan tujuan akhirat, membesarkan himmah menghadap Allah dengan suluk, mengalahkan nafsu dengan latihan batin (riyadhah) dan dengan perjuangan (mujahadah) sehingga tersingkapalah hijab dan terbukalah kasy-syaf, hingga pada akhirnya sampailah 
kepada masyahadatul-qlabi yang menghilangkan keraguan dan hasilnya ma'rifatullah. Dengan keyakinan tersebut, tasawwuf Al-Ghozali dikenal sebagai Tasawwuf Ahlus-sunnah, dan beliau berkeyakinan bahwa dengan tasawwuf, maka adanya Allah semakin dapat terasa.

5. Ibnu -'Arabi (Muhammad bin Ali bin Ahmad bin Abdullah Abu Bakar Muhyiddin Ibnu 'Arabi Al-Hatimi At-Tha'i Al-Andalusi (11165 - 1240) Masehi. Beliau terkenal sebagai tokoh filsafat yang dikombinasikan dengan tasawwuf. Teori yang terkenal dalam dunia tasawwuf adalah; Wihdatul-Wujud, Al-HaqiqatulMuhammadiyyah, dan Kesatuan Agama.

Dalam teori Wihdatul-wujud, Al-'Arabi berpendapat bahwa Wujud Mackhluk adalah 'Ain dari wujudnya Khaliq (sang pencipta) yang pada hakekatnya tak ada perbedaan antara keduanya. Kemudian mengenai $\mathrm{Al}$-Haqiqatul-Muhammadiyyah; Allah adalah satu, sebagai wujud mutlak dan nurnya adalah bagian daripada diriNya sebagai kenyataan Uluhiyah (uluhiyah dalah ke-esaan dan kekuasaan-Nya) dan Rububiyah (ke-esaan dalam mengatur, memelihara dan menjaga kesempurnaan alam). Mengenai teori tentang Kesatuan Agama, Ibnu-'Arabi berpendapat bahwa yang disembah oleh semua penganut agama adalah Dia Yang Maha Esa, yaitu Allah. Adapun patung, batu, api, Ka'bah adalah sekedar lambang, sekalipun tidak ada lambang yang berbentuk, apabila Allah yang disembah, maka ibadahnya adalah sah. Dalam hal ini Ibnu-' Arabi mengakui bahwa Ka'bah adalah kiblat, tetapi menghadap kiblat bukanlah merupakan syarat syah sembahyang.

Dengan teori ini, akibatnya Ibnu-'Arabi ditentang oleh para sufi dari kalangan (Tasawwuf Sunnah) antara lain Ibnu Taimiyah.

6. Ibnu Taimiyah (Taqiyuddin Abul-'Abbas Ahmad bin Abdul-Halim bin abdussalam bin abdillah bin Muhammad bin Taimiyah Al-Harrani Al-Hambali, 1263 - 1328 Masehi). Keyakinan yang kemudian menjadi pendiriannya adalah; Hubungan antara khaliq dengan makhluq adalah langsung (tidak boleh memakai perantara atau wasilah), Perhubungan langsung itu berpedoman pada petunjuk Rasulullah saw dengan lengkap, tidak boleh lebih dan tidak boleh kurang yang berakibat akan meninggalkan derajat iman, Dan Muhammad adalah hamba dan utusan Allah ('abduhu wa-rasuluh) dan siapapun yang memakai cara hidup sebagaimana beliau gariskan, maka dia dapat menjadi waliyullah.

Dalam sosialisasi Islam yang merupakan suatu proses masyarakat muslim untuk berintegrasi dengan sesamanya menurut sistem nilai, norma atau adat-istiadat yang ada di masyarakat, (Suyono, 1985 : 379), Islam muncul di Nusantara dari fenomena suatu kegiatan perdagangan, kemudian berlanjut dengan meluasnya imperium, pusat kekuasaan Islam dan kemudian berujung pada kolonialisme barat. Dalam sosialisasi 
Islam, perkembangnan politik, ekonomi dan panggilan agama ikut tampil sebagai motivațor yang ikut menentukan corak, penyebaran pengembangan dan bentuk masyarakat muslim di tiap-tiap wilayah atau tempat terjadinya sosialisasi.

Di Indonesia, proses tersebut berlangsung melalui tahapan, meskipun antara satu tempat dengan tempat yang lain berbeda, yaitu tumbuhnya komunitas muslim, baik di daerah pantai maupun di daerah pedalaman. Dalam sosialisasi Islam tersebut awalmulanya diprakarsai oleh orang-orang alim dan tidak hanya ahli di bidang keagamaan saja, tetapi juga ahli di bidang setrategi pengembangnannya. Di samping itu mereka juga tidak hanya menetap di kota saja, tetapi juga masuk ke daerah-daerah pedalaman. Disamping itu dalam proses sosialisasi Islam tidak akan terlepas dari strategi dakwah yang dilakukan oleh para tokoh penyebar Islam, mulai dari mendirikan masjid, mengadopsi kesenian lokal menjadi kesenian yang bermuatan Islam, mendidik kader ulama, dakwah langsung kepada para penguasa dan keluarganya ataupun dengan pendekatan langsung kepada masyarakat. Setrategi semacam ini dapat dilakukan melalui perdagangan, perkawinan, diskusi atau pendalaman tentang keagamaan Islam, (Ambary, $1998: 61$ ). Atau dengan kata lain dapat dilakukan dengan misi keagamaan dan misi kebudayaan.

Datangnya Islam di Indonesia memang tidak meningggalkan monumen-monumen besar seperti Borobudur, Prambanan dan bangunan-banguna hindu dan budha yang lain, dan tidak pula sepeti umat Islam di Spanyol yang memiliki monumen besar AlHambra atau seperti umat Islam di India , yaitu dengan tinggalan bangunan megah "Tajmahal". Tetapi masjid-masjid lama Indonesia sangat sederhana bentuknya, sesuai dengan kondisi mayoritas lapisan masyarakat penerima agama baru tersebut.

Pada akhir abad XIII Masehi perambatan Islam di kalangan rakyat Idonesia telah dimulai. Pada awal munculnya Islam, kita hanya mempunyai sedikit informasi, karena dokumen-dokumen yang ada umumnya berasal dari abad enam belas dan tujuh belas. Dokumen-dokumen tersebut umumnya bermuatan puisi-puisi mistis atau tasawwuf (Grunebaum, $1983: 330$ ).

Dari karya-karya sastera yang ada, antara teks-teks yang berasal dari Jawa dan teksteks yang berasal dari Sumatra terdapat suatu perbedaan yang jelas. Karya sastera yang berasal dari Sumatera menampilkan tokoh-tokoh yang khrismatik, seperti: Hamzah Fansuri, Nuruddin Arraniri, Abdur-rauf Singkel, Syamsuddin As-Sumatrani. Sedangkan karya-karya sastera yang berasal dari Jawa berifat impersonal yang pada umumnya merupakan karya yang khas bagi sebagian karya-karya Jawa.

Hamzah Fansuri dan murid-muridnya adalah pengikut aliran mistis (tasawwuf), yaitu aliran yang meyakini adanya martabat tujuh, sementara oleh aliran lain yang menentang terhadap keyakinan tersebut, mereka disebut sebagai "Wujudiyah Bid'ah", 
karena aliran yang mereka anut memiliki doktrin yang dijabarkan dari eksistensialisme Ibnul-'Arabi yang mengajarkan bahwa semua benda yang ada di alam semesta ini harus terpancar dari pra-pengetahuan ke-ilahian.

Dalam martabat tujuh di ajarkan bahwa segala yang ada di alam semesta ini, termasuk manusia adalah aspek lahir dari suatu hakekat yang tunggal, yaitu Tuhan. Tuhan sebagai Dzat yang mutlak tidak dapat dikenal oleh indera, akal dan khayal, Dia dapat dikenal setelah bertajalli (menampakkan diri ke luar sebanyak tujuh martabat, hingga tercipta alam semesta beserta isinya termasuk manusia sebagai aspek lahir daripada Dzat Tuhan. Tiga Tajalli yang pertama adalah; martabat Ahadiyah (kesatuan mutlak), martabat Wahdah (kesatuan yang mengandung kejamakan secara ijmal), dan martabat Wahidiyah (kesatuan dalam kejamakan secara terperinci batas-batas setiap sesuatu. Kemudian dari ketiga martabat tersebut muncullah tiga martabat yang merupakan aspek lahir, yaitu alam Arwah, alam mistal (kesatuan dalam kejamakan secara ijmal), dan alam Ajsam (alam segala tubuh, kesatuan dalam kejamakan secara terperinci). Ketiga martabat lahir dan martabat batin terkumpul dalam martabat yang ke tujuh, yaitu alam Insan (Simuh, $1988: 308$ ).

Di Jawa, mistisisme secara sistematis muncul setelah masuknya Islam, dimana sistem perlambangan yang ada lebih banyak ditimba dari perlambangan yang dikenal dalam tasawwuf Islam. Istilah Kawula Gusti yang dikenal dalam mistik Jawa adalah terjemahan dari istilah hamba Tuhan di dalam tasawwuf. Oleh karena itu sangat diragukan bila mistisisme yang berkembang di Indonesia, khususnya di Jawa adalah atas jasa Hinduisme dan agama Budha yang sebelumnya telah berkembang dengan pesat, karena kitab-kitab tentang mistik pada masa-masa itu sangat sulit ditemukan. Tetapi sebaliknya, nama-nama seperti Al-Hallaj, Ibnu 'Arabi, Abdul-Karim Al-Jili, Imam Ghozali, Syekh Abdul-Qadir Al-Jailani dan lain-lain sangat populer dan senantiasa banyak disebut dalam kitab-kitab tasawwuf di Indonesia.

Awal-mula hadirnya Islam di Jawa bermula dari peran kegiatan sejumlah wali (abad XVI Masehi), yang sebagian besar mereka adalah pengikut aliran mistik yang amat tegas coraknya. Meskipun proses pengislaman terhadap masyarakat Jawa merupakan sederetan peristiwa yang sangat kompleks, tetapi tradisi Jawa telah mampu memampatkan periode perubahan religius, menjadi suatu peristiwa yang sangat penting, yaitu runtuhnya sebuah kerajaan besar (Majapahit) yang oleh sebagian orang berpendapat, bahwa runtuhnya kerajaan besar tersebut adalah akibat intervensi para Walisongo. Diantara walisongo yang mengajarkan Islam dan mistisisme (tasawwuf) antara lain Sunan Bonang. Ajaran sufis yang diberikan antara lain bantahan terhadap ajaran sufis yang dianggap sesat yang beranggapan bahwa apa yang ada adalah Allah dan apa yang tidak ada adalah Allah. Tetapi menurut ajaran Sunan Bonang bahwa Allah itu adalah lebih dari apa yang digambarkan oleh manusia, Allah Maha Tinggi dan Maha Luhur. Dia Maha Suci, tidak didahului dan diiringi oleh ketiadaan, sebab 
Dia adalah Qadim (dahulu tak berpermulaan). Tokoh yang lain adalah Syekh Siti Jenar (Al-Hallaj-nya masyarakat Jawa) dengan ajarannya Kawulagusti, yang menganggap bahwa dirinya adalah Tuhan, sehingga mendapat tanntangan keras dari para wali yang lain (Sartono, $1975: 145$ ).

Kemudian pada permulaan abad XVII Masehi, sejak berdirinya kerajaan Mataram Islam, mistik Islam telah mengalami pertumbuhan dan perkembangan yang pesat. $\mathrm{Hal}$ ini dapat diketahui melalui beberapa serat suluk (pada masa Panemabahan Seda Krapyak 1601 - 1613 M) yang telah mempertemukan antara tradisi Jawa dengan unsur-unsur ajaran (mistik Islam), sebagaimana Serat Suluk Wijil, yang berisi tentang Wejangan Sunan Bonang kepada Wujil (seorang bujang bekas budak Majapahit).

Sultan Agung, pada tahun 1613 - 1645 telah menjalankan politik Islamisasi dengan mempertemukan tradisi Jawa dengan agama Islam, misalnya dalam hal penyusunan perhitungan tahun Jawa yang sesuai dengan tahun Hijriyah sebagai ganti tahun Saka yang merupakan upaya islamisasi terhadap tradisi atau budaya yang ada.

Kemudian pada pertengahan abad XVIII, setelah terjadi perjanjian Gianti, dengan terbaginya wilayah Mataram (Kasunanan dan Kasultanan) dan semua kekuasaan telah dirampas oleh Belanda, akhirnya perhatian istana diarahkan kepada kegiatan perkembangan kebudayaan rohani. Pada kegiatan tersebut diantaranya telah menghasilkan karya-karya sastera yang cukup besar, sebagai gubahan dan terjamahan dari karya, karya sastera yang ada pada masa sebelumnya dengan memanfaatkan perbendaharaan yang terdapat dalam Islam, (Poebatjaraka, 1952 : 152). Diantara karya-karya yang terkenal adalah ; Serat Cabolek , karya Yasadipura I yang memuat tentang Mistik Islam kejawen, yaitu menghubungkan antara ajaran Serat Dewaruci yang memuat tentang penghayatan gaib yang dialami Aryasena dalam badan Dewaruci dengan persoalan yang berhubungan dengan konsep Kesatuan Kawula Gusti (konsep Wihdatul-Wujud).

Dari sekian banyak karya-karya sastera yang cenderung memuat ajaran-ajaran mistis atau tasawwuf menunjukkan bahwa tenyata Islam dan sufismenya telah memiliki daya tarik di kalangan para sasterawan muslim di masa lalu. Hal ini disebabkan selain karena relevansinya bagi manusia, juga karena pandangan estetiknya yang lebih memuaskan, dibanding pandangan estetik humanis Barat. Sebab bagi kebudayaan Barat, apa yang dinamakan keindahan (estetik) adalah merupakan suatu kemewahan, tetapi bagi Islam, pandangan estetik keindahan merupakan suatu rahmat atau karunia yang wajar dari Tuhan Yang Maha Kuasa. Keindahan merupakan bagian dari sifat Tuhan yang memiliki nilai spiritual dan pembebasan dari kehidupan kebendaan, sehingga dalam Islam, keindahan adalah merupakan bukti keilahian. 
Di sisi lain Kebudayaan memandang keindahan sebagai nilai tempat bergantungnya validitás Islam itu sendiri. Menurut Ismail $\mathbf{R}$ Faruqi dalam bukunya Islam dan Kebudayaan, dalam menjawab pertanyaan apakah Al-Qur'an benar-benar merupakan wahyu Tuhan dan bukan bikinan manusia yang relatif sifatnya, adalah nilai keindahan Al-Qur'an sendiri ( R.Faruqi, Ismail, $1984: 69$ ).

Para sufi menyadari hal ini, mereka terangsang oleh keindahan bahasa Al-Qur'an, bahkan tidak ada kitab suci yang demikian memberikan rangsangan terhadap lahirnya karya-karya sastera yang tinggi nilainya seperti Al-Qur'an, dan hampir-hampir tak ada gerakan mistis kecuali mistik Islam, yaitu tasawwuf.

Ajaran-ajaran tasawwuf berkaitan erat dengan tarekat yang tentunya diawali dengan syari'at, sebab barang siapa menjalani tasawwuf dengan tidak didasari syari'at maka apa yang dilakukan adalah menyimpang. Jumlah tarekat sangat banyak, hampir mencapai seratusan (Umarie, $1966: 101$ ), akan tetapi diantara tarekat-tarekat yang berkembang di Indonesia antara lain tarekat Qadiriyah, Naqsabandiyah, Sammaniyah, Quahashiyah, Syattariyah, Syadziliyah, Khalwatiyah dan Tijaniyah (Sartono, 1975 : 146).

Sebelum timbul organisasi-organisasi tarekat, jauh sebelum abad 15 Masehi, di masyarakat Indonesia telah berkembang amalan-amalan tarekat yang semata-mata merupakan aliran-aliran dári doktrin tasawwuf. Adapun organisasi-organisasi tarekat pada awal pertumbuhannya merupakan kelanjutan daripada paham-paham tasawwuf yang berkembang sejak abad 9 Masehi, sehingga istilah tarekat tetap dipakai sesuai dengan artinya, yaitu cara atau jalan yang ideal menuju Allah dengan menekankan aspek-aspek doktrin disarhping praktek-praktek ritual yang tidak menyimpang dari ajaran-ajaran yang diberikan Nabi Muhammad saw dan para sahabatnya (Dhofier, $1984: 136$ ).

Di Jawa, pada awal perkembangan Islam, Demak, Pajang dan Mataram Islam, turut secara aktif dalam melancarkan proses Islamisasi. Tetapi dengan datangnya Belanda di Jawa untuk memonopoli perdagangan di Jawa dan tidak simpatinya terhadap perkembangan Islam, maka perkembangan Islam di Jawa agak terhambat, akibatnya pola kehidupan keagamaan yang semula berkembang pesat di kota-kota akhirnya berpindah ke daerah-daerah pedalaman dengan mendirikan lembaga-lembaga pendidikan, yang dikenal dengan istilah pesantren. Langkah ini merupakan bentuk lain setelah elemen-elemen perdagangan di Jawa mengalami kehancuran, sebagai akibat dari upaya Belanda untuk memonopoli perdagangan, baik di dalam maupun di luar negeri. Dalam misi pengembangan Islam melalui pesantren, para tokoh menekankan kepada para pengikut (masyarakat ataupun santri) akan pentingnya sembahyang dan dzikir, sebagai upaya peningkatan kehidupan spiritual yang pada dasarnya menyebut-nyebut nama Tuhan untuk melepaskan keterikatan dengan alam 
duniawi dan menyadari hakekat dirinya sebagai makhluk Tuhan, sehingga akan memudahkan dirinya untuk mendekatkan diri kepada Tuhan (Allah SWT) yang merupakan tujuan dan kebahagi hidup yang paling utama. Hal ini menunjukkan bahwa doktrin-doktrin tersebut tidak terlepas dari doktrin yang ada pada ajaran-ajaran tasawwuf.

\section{Kesimpulan}

Tasawwuf merupakan suatu kajian yang sangat menarik dan relevan bagi perkembangan Islam dan Kebudayaan Islam di Indonesia, sebab berdasarkan beberapa kenyataan yang ada, bahwa tersebarluasnya Islam di pelosok Nusantara adalah disebabkan oleh kegiatan para sufi. Sebagai bukti dari ajaran ajaran tasawuf, terdapat pada beberapa hasil karya kesusasteraan taradisional Melayu, Aceh, Minangkabau, Bugis, Makasar, Sunda, Jawa dan lain sebagainya. Banyak peningggalan karya-karya sastera peningglan zaman Hindu yang masih hidup pada zaman Islam. Karya-karya tersebut bukan hanya sekedar dipelihara atau dilestarikam dalam bentuk fisik, tetapi disalin kembali agar tidak kehilangan arti sebagai dokumen peninggalan suatu zaman tertentu. Masjid-masjid lama yang memiliki corak khas Indonesia dibangun berdasarkan gagasan-gagasan yang hidup di kalangan para sufi, yaitu suatu kesatuan empat yang tidak dapat dipisahkan dalam pelaksanaan ajaran Islam; syari'at, tarekat, hakekat dan ma'rifat. Di sisi lain bentuk lama dari suatu bangunan masjid dengan bentuk atapnya yang umumnya bersusun tiga ditransformasikan dalam bentuk bangunan pra -Islam. Akan tetapi dengan memberikan makna simbolis baru yang khas Islami, akhirnya mampu mengubah seperlunya serta menyingkirkan unsur-unsur yang bertentangan dengan Islam, sehingga lahirlah suatu konsep baru di bidang arsitektur.

Dari sekian banyak karya-karya sastera yang cenderung memuat ajaran-ajaran mistis atau tasawwuf menunjukkan bahwa tenyata Islam dan sufismenya telah memiliki daya tarik di kalangan para sasterawan muslim di masa lalu. Hal ini disebabkan selain karena relevansinya bagi manusia, juga karena pandangan estetiknya yang lebih memuaskan, dibanding pandangan estetik humanis Baratm, sebab bagi Islam, pandangan estetik keindahan merupakan suatu rahmat atau karunia yang wajar dari Tuhan. Keindahan merupakan bagian dari sifat Tuhan yang memiliki nilai spiritual dan pembebasan dari kehidupan kebendaan, sehingga dalam Islam, keindahan adalah merupakan bukti keilahi. Dengan demikian nampak semakin jelas, bahwa di Indonesia, tasawwuf memiliki peranan yang cukup penting dalam proses sosialisasi Islam. 


\section{KEPUSTAKAAN}

Dhofier, Zamahsyari, 1984, Tradisi Pesantren, LP3ES, Jakarta.

Grunebaum, Gustave E.Von, 1983, Islam Dalam Kesatuan dan Keragaman, Yayasan Obor Indonesia, Jakarta.

Hamka, 1952, Perkembangan Tasawuf Dari Abad ke Abad, Djakarta .

Ismail Hamid, 1983, Kesusasteraan Melayu Lama Dari Warisan Peradaban Islam, Petaling Jaya, Fajar Bakti.

Poerbatjaraka dan Tardjan Hadidjaya, 1952, Kepustakaan Jawa, Jambatan, Jakarta.

R. Faruqi, 1smail, 1984, Islam dan Kebudayaan, Mizan, Bandung.

Sartono Kartodihar, 1975, Sejarah Nasional Indonesia III, Jaman Pertumbuhan dan Perkembangan Kerajaan-Kerajaan Islam di Indonesia, Departemen Pendidikan dan Kebudayaan, Jakarta.

Simuh, 1988, Mistik Islam Kejawen, UI Press, Jakarta.

Suyono, Ariyono, 1985, Kamus antropologi, Akademika Presindo, Jakarta.

Umarie, Barmawie, 1966, Systematik Tasawwuf, AB. Siti Sjamsijah, Sala.

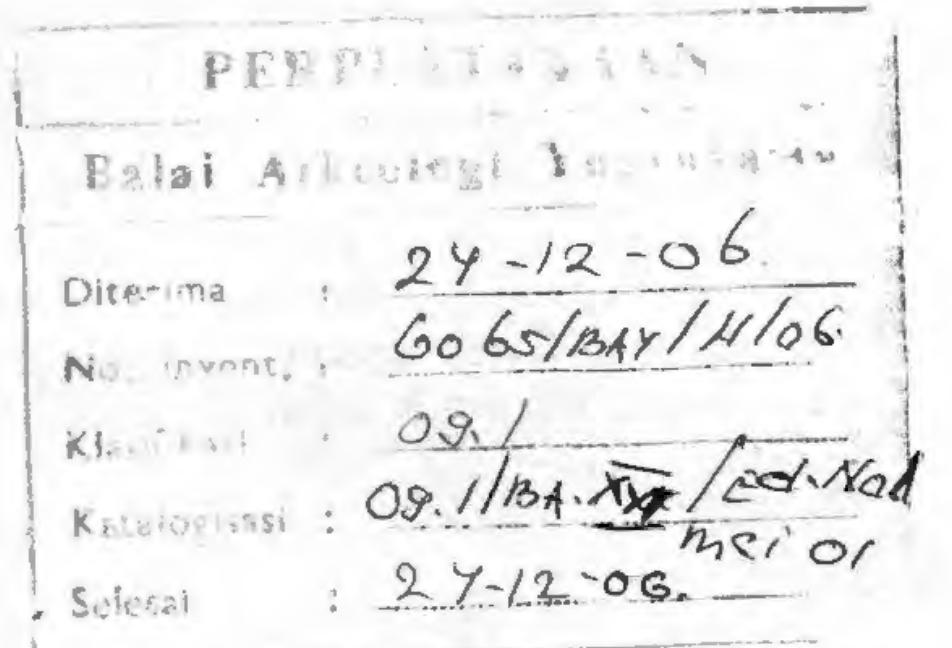

